\title{
Mitos dan Budaya Kaapunan Masyarakat Gantung, Belitung Timur di Tengah Masyarakat Global-Mulikultural
}

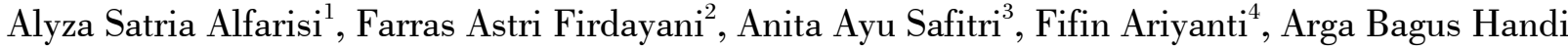 \\ Pradana ${ }^{5}$ \\ 1,2,3,4,5 Fakultas Keguruan dan Ilmu Pendidikan, Universitas Muhamamdiyah Surakarta, Indonesia
}

\section{INFORMASI ARTIKEL}

\section{Histori Artikel:}

Submit : 10 Juni 2019

Direvisi : 20 Juni 2019

Diterima : 29 Juni 2019

Publikasi : 1 Juli 2019

\section{Kata Kunci:}

budaya

mitos

kepercayaan

\section{Correspondent Author:}

Alyza Satria Alfarisi

Fakultas Keguruan dan Ilmu Pendidikan

Universitas Muhammadiyah Surakarta,

Indonesia

Email:al.fa.com.af@gmail.com

\begin{abstract}
ABSTRAK
Budaya adalah salah satu bentuk keragaman yang sangat erat kaitannya dengan suatu daerah dan masyarakat tertentu. Budaya banyak memiliki daya tarik bagi siapapun yang mengilhaminya. Banyak daerah-daerah di Indonesia yang memiliki budaya yang sangat luar biasa indahnya. Dusun Rasau Desa Gantung Belitung Timur memiliki budaya yang unik serta menimbulkan rasa tidak percaya bagi siapapun yang baru mendengarnya. Dusun Rasau Desa Gantung senidri memiliki banyak mitos-mitos yang banyak menimbulkan rasa tak percaya, namun memberikan banyak pesan moral serta pelajaran hidup. Dari banyaknya mitos yang ada diceritakan, ada satu mitos atau kepercayaan masyarakat Desa Gantung yang ampuh dan benar-benar bias memberikan imbal balik. Mitos tersebut adalah "kaapunan" yaitu tidak boleh menolak, tidak boleh takabur, tidak boleh mengatakan sesuatu dengan dilisankan atau diucapkan secara terang-terangan. Apabila hal tersebut dilanggar maka orang yang telah melanggar akan mendapatkan suatu musibah, entah itu jatuh, tenggelam atau musibah lain. Mitos tersebut amat sangat ditakuti oleh masyarakat disana, namun bukan dengan maksud yang negatif, masyarakat disana menghormati dengan apa yang ada, bahwa memang bersifat takabur adalah dilarang oleh agama.
\end{abstract}

\section{Pendahuluan}

Budaya adalah salah satu bentuk keragaman yang sangat erat kaitannya dengan suatu daerah dan masyarakat tertentu. Budaya banyak memiliki daya tarik bagi siapapun yang mengilhaminya. Banyak daerah-daerah di Indonesia yang memiliki budaya yang sangat luar biasa indahnya. Budaya juga banyak mengajarkan kita bagaimana mengetahui dan menghormati budaya yang timbul atau tumbuh berkat rasa toleran dan rasa peduli terhadap hal-hal yang tumbuh dari suatu kebiasaan yang menghasilkan sesuatu yang positif. Salah satu budaya yang belum kita ketahui adalah budaya yang terdapat di Dusun Rasau, Desa Gantung Belitung Timur. Banyak budaya yang sangat kental lahir dan berkembang disana. Percaya atau tidak percaya, masyarakat disana masih sangat kental dengan budaya peninggalan nenek moyang mereka. Masyarakat disana percaya bahwa semua benda dan tempat pasti berkaitan dengan energi yang berhubungan dengan energi supranatural dan dunia metafisik. Mereka 
percaya bahwa sukma nenek moyang mereka atau pendahulu mereka masih ada disana.

Budaya yang seperti itu sangatlah dipandang menakutkan oleh sebagian orang yang tidak mempercayai hal-hal yang berbau metafisik. Bahkan pasti dipandang menyimpang karena masih berkaitan dengan kepercayaan animisme dan dinamisme. Banyak maknamakna konotasi yang sangat sulit diterjemahkan oleh orang awam. Kita sebagai manusia seharusnya menghormati dengan hal-hal seperti itu. Seperti halnya banyak budaya ditempat lain yang juga demikian, mempercayai hal-hal ghaib dan energi supranatural.

Dusun Rasau Desa Gantung Belitung Timur memiliki mitos yang unik serta menimbulkan rasa tidak percaya bagi siapapun yang baru mendengarnya. Salah satunya adalah budaya yang mempercayai bahwa apapun yang ada disana, entah tempat atau benda tidak boleh ditunjuk dengan terang-terangan, tidak boleh mengatakan "pengen" atau mengatakan dengan terang-terangan hal yang diinginkan dengan dilisankan yang biasa disebut "Kaapunan". Adalagi yaitu tidak boleh takabur, atau tidak boleh menyombongkan diri atau menantang sesuatu yang ada disana, semisal mengenai keberadaan hal-hal ghaib.

Mitos (myth) adalah cerita rakyat yang tokohnya para dewa atau makhluk setengah dewa yang terjadi di dunia lain atau masa lampau dan dianggap benar-benar terjadi oleh penganut cerita tersebut. Mitos berasal dari bahasa Yunani muthos yang berarti dari mulut ke mulut, atau dengan kata lain cerita informal suatu suku yang diteruskan dari satu generasi ke generasi berikutnya (Christensen, 2008). Biasanya mitos menceritakan mengenai terjadinya alam semesta, dunia, bentuk khas binatang, bentuk topografi, petualangan para dewa, dan sebagainya. Mitos hampir sama halnya dengan legenda. Hanya saja legenda (legend) adalah cerita rakyat yang dianggap benar-benar terjadi dan biasanya mengenai manusia, kekuatan supranatural, tempat, atau objek. Legenda tidak terlalu dianggap suci seperti mitos. Salah satu contohnya adalah mitos yang berkembang didalam kehidupan masyarakat Dusun Rasau, Desa Gantung, Belitung Timur.

Mitos di Indonesia dapat dibagi menjadi dua macam berdasarkan tempat asalnya, yakni asli Indonesia dan berasal dari Luar Negeri, terutama dari India, Arab, dan sekitar Laut Tengah. Mitos di Indonesia biasanya menceritakan terjadi alam semester (kosmogenik), yaitu terjadinya susunan para dewa, terjadinya manusia pertama dan tokoh pembawa kebudayaan. Keberadaan mitos di Indonesia telah menjadi bagian dari kehidupan di masyarakat (Andalas, 2017). Dalam dunia modern, mitos juga memiliki fungsi dalam kehidupan sehari - hari dan dalam organisasi kehidupan bermasyarakat. Kepercayaan terhadap mitos membentuk pola pikir manusia dan bahkan nilai - nilai dalam berorganisasi. Hubungan manusia dan alam yang terjalin karena kepercayaan berupa mitos menunjukkan hubungan relasional yang bermanfaat bagi kehidupan manusia dalam menjaga lingkungan alam (Angeline, 2015). Mitos merupakan unsur kebudayaan yang hampir ada di setiap kelompok masyarakat di seluruh dunia. Keberadaan suatu mitos tidak terlepas dari fungsinya terhadap masyarakat pendukungnya. Mitos tidak hanya terbatas pada semacam reportasi mengenai peristiwa yang dulu terjadi, berupa kisah dewa-dewa dan dunia ajaib, tetapi memberikan petunjuk kepada kelakuan manusia. Dalam hubungan manusia dengan alam, mitos dijadikan media konservasi karena dapat memberikan pengetahuan terkait dengan gejala alam yang akan menyebabkan berbagai 
dampak bagi kehidupan manusia (Nensiliansi, 2019).

Artikel ini bertujuan untuk mengetahui latar belakang serta hubungan antara mitos dan budaya terhadap masyarakat Belitung Timur khususnya di Dusun Rasau, Desa Gantung, Belitung Timur. Pembahasan ini diharapkan bermanfaat bagi semua orang untuk memberikan pengetahuan tentang budaya serta mitos yang berkembang terhadap masyarakat khususnya di Dusun Rasau Desa Gantung Belitung Timur.

\section{Metode Pelaksanaan}

Penelitian ini dilakukan di Dusun Rasau Desa Gantung Belitung Timur selama kurang lebih 1 bulan, yaitu pada tanggal 23 Juli - 26 Agustus 2019. Jenis penelitian ini menggunakan deskriptif kualitatif. Membaca beberapa cerita atau artikel untuk melihat bagaimana budaya dan mitos yang berkembang. Budaya dan mitos khususnya yang berkembang di Dusun Rasau Desa Gantung Belitung Timur banyak yang belum diketahui oleh banyak orang serta terdapat banyak pesan moral yang terdapat didalamnya. Dengan objek penelitian ini, peneliti akanmemberikan informasi dan mendeskripsikan budaya serta mitos yang ada di Dusun Rasau Desa Belitung Timur. Subjek penelitian ini adalah warga masyarakat Belitung Timur asli serta masyarakat suku Bugis. Artikel ini dibuat dengan cara penulis mengobservasi masyarakat pada saat warga masyarakat melakukan aktifitas seharihari dan pada saat bersosialisasi.

\section{Hasil Pelaksanaan dan Pembahasan}

Dusun Rasau Desa Gantung Belitung Timur memiliki budaya yang unik serta menimbulkan rasa tidak percaya bagi siapapun yang baru mendengarnya. Dusun Rasau Desa Gantung memiliki jarak tempuh kurang lebih 45 menit perjalanan dari Kecamatan Gantung dan 2 jam dari pusat kota, yaitu Tanjung Pandang. Banyak budaya yang ada di Belitung, berbagai ragam jenis bahkan ratusan budaya yang berkembang dan lahir disana entah dari segi tempat, cara hidup, suku-suku, serta kebiasaankebiasaan yang lahir dari peninggalan nenek moyang tedahulu yag biasanya menuai banyak mitos yang mengalir. Khusunya di Dusun Rasau Desa Gantung senidri memiliki banyak mitosmitos yang banyak menimbulkan rasa tak percaya, namun memberikanbanyak pesan moral serta pelajaran hidup. Salah satunya adalah mitos yang mempercayai bahwa apapun yang ada disana, entah tempat atau benda tidak boleh ditunjuk dengan terang-terangan, tidak boleh mengatakan "pengen" atau mengatakan dengan terang-terangan hal yang diinginkan dengan dilisankan yang biasa disebut "Kaapunan". Adalagi yaitu tidak boleh takabur, atau tidak boleh menyombongkan diri atau menantang sesuatu yang ada disana, semisal mengenai keberadaan hal-hal ghaib.

Ali Akbar (17), salah satu siswa di MA Muhammadiyah Gantung memberikan sedikit informasi mengenai orang Bugis yang menyebut buaya dengan sebutan "nenek". Ali memberikan informasi bahwa suku Bugis atau orang Bugis menamai buaya dengan sebutan "nenek" disebabkan oleh legenda pada jaman dahulu ada seorang pangeran yang melanggar aturan dan kemudian dikutuk menjadi seekor buaya. Selain itu ia juga memberikan informasi tentang kebudayaan yang ada dilingkungan Desa Gantung. Kebudayaan tersebut seperti Mongjong (sedekah bumi/ larungan) dan Maras Tahun (selamatan/ syukuran).

Dijelaskan juga bahwa di Desa Gantung juga masih kental dengan kepercayaan yang 
berbau mistis, atau masih mempercayai orang pintar yang disebut "dukun". Dukundukun disana bukan hanya terdapat satu jenis dukun, tetapi dukun disana dibagi-bagi berdasarkan tempat, seperti Dukun Air dan Dukun Darat. Penamaan itu berdasarkan dari tempat manusia beraktifitas, ketika ada orang hilang di air, maka yang dibutuhkan adalah dukun air, begitupun ketika ada orang yang hilang dihutan atau kesurupan maka dukun daratlah yang dibutuhkan.

Dari banyaknya mitos yang ada diceritakan, ada satu mitos atau kepercayaan masyarakat Desa Gantung yang ampuh dan benar-benar bias memberikan imbal balik. Mitos tersebut adalah "kaapunan" yaitu tidak boleh menolak, tidak boleh takabur, tidak

boleh mengatakan sesuatu dengan dilisankan atau diucapkan secara terangterangan. Apabila hal tersebut dilanggar maka orang yang telah melanggar akan mendapatkan suatu musibah, entah itu jatuh, tenggelam atau musibah lain. Mitos tersebut amat sangat ditakuti oleh masyarakat disana, namun bukan dengan maksud yang negatif, masyarakat disana menghormati dengan apa yang ada, bahwa memang bersifat takabur adalah dilarang oleh agama. Menurut masyarakat mitos-mitos yang ada sebenarnya lahir bukan tanpa maksud, mitos yang ada memberikan banyak pesan moral dan pelajaran bagi siapapun yang bisa berfikir. Bahwa mempercayai hal-hal yang ghaib itu memang benar adanya, ada kehidupan yang memang berdampingan dengan kita.

Masyarakat juga berpandangan bahwa kita harus menghormati dan menjaga apa-apa yang telah orang lain atau orang yang terdahulu seperti peninggalan nenek moyang untuk dijaga dan dilestarikan. Mitos yang ada di masyarakat pun bukan alasan mereka untuk tidak percaya dengan agama yang mereka yakini. Mitos disana membuat masyarakat semakin mempererat silaturahmi, gotong royong, dan rasa kekeluargaan antar sesama. Menjaga segala apa yang ada di bumi, selalu memperbaiki perilaku serta menjaga tingkah laku dengan memperhatikan tempat yang didiami dan percaya bahwa ada kehidupan lain yang berdampingan dengan kita adalah salah satu cara untuk mempererat rasa kekeluargaan dan toleransi serta menghindari sifat tercela seperti takabur.

\section{Simpulan}

Dari hasil analisis pada penelitian ini, dapat diambil kesimpulan sebagai berikut :

a. Mitos yang ada sebenarnya lahir bukan tanpa maksud, mitos yang ada memberikan banyak pesan moral dan pelajaran bagi siapapun yang bisa berfikir. Bahwa mempercayai hal-hal yang ghaib itu memang benar adanya, ada kehidupan yang memang berdampingan dengan kita.

b. Mitos tersebut amat sangat ditakuti oleh masyarakat disana, namun bukan dengan maksud yang negatif, masyarakat disana menghormati dengan apa yang ada, bahwa memang bersifat takabur adalah dilarang oleh agama. Dari kisah mitos disana dapat diambil pengaruh positif seperti mempererat tali silaturahmi, gotong royong dan rasa kekeluargaan diantara sesama.

\section{Daftar Pustaka}

Akhlak, Annisa; Arifin, M. Bahri; Rijal, Syamsul. (2019). "Pemali dalam Masyarakat Etnik Banjar di Kota Samarinda : Suatu Tinjauan Semiotika". Ilmu Budaya. 3(2) : 121-130.

Andalas, Eggy Fajar. (2017). "Dampak dan Fungsi Sosial Mitos Mbah Bajing Bagi 
Kehidupan Spiritual Masyarakat Dusun Kecopokan, Kabupaten Malang, Jawa Timur".

Jurnal Puitika. 13 (1) : 20-31.

Angeline, Mia. (2015). "Mitos dan Budaya".

Humaniora. 6 (2) : $190-200$.

Anggara, Sahya. (2018). "Pelestarian Budaya Suku Sawang di Kabupaten Belitung Timur".

Panggung. 28 (3) : 360 - 373.

Humaeni, Ayatullah. (2012). "Makna Kultural Mitos dalam Budaya Masyarakat Banten".

ANTROPOLOGI INDONESIA. 33 (3) : 156-180.

Margaretha, Risma. (2017). "Analisis Klasifikasi Mitos dalam Tradisi Lisan Masyarakat

Lampung". Pendidikan Progesif. VII (2) : 117 126.

Nensilianti. (2019). "Kategori dan Karakteristik Mitos Masyarakat Bugis dan Makassar". Retorika. 12(1) : 53-70.

Nurmalina. (2015). "Pantang Larang dalam Masyarakat Kampar dann Relevansinya dengan Pendidikan Karakter". JURNAL PAUD TAMBUSAI. 1 (1) : 27-35.

Pujaastawa, I. B. G dan Suwena, I Wayan. (2013). "Kearifan Lokal di Balik Mitos Lembu

Putih di Desa Taro, Gianyar". Jurnal Bumi Lestari. 13 (2) : 430 - 440.

Wardyaningrum, Damayanti. (2018). "Kepercayaan Masyarakat Terhadap Informasi

Tradisional dan Modern Pada Peristiwa Bencana Alam". ASPIKOM. 3 (4) : 609 622.

Wildan, Asep Dadan dan Irwandi. (2018). "Peran Dukung Kampung Dalam Kehidupan Masyarakat Melayu Belitung".
KELOLA : Jurnal Ilmu Sosial. 1 (1) : 1 16. 